\title{
Menggali Keunikan Desa Mewujudkan Desa Wisata Di Desa Jernih Jaya Kabupaten Kerinci
}

\section{Sry Rosita, Johanes Simatupang, Sylvia Kartika Wulan Bhayangkari, Ade Titinifita, Husni Hasbullah}

Fakultas Ekonomi dan Bisnis, Universitas Jambi, Indonesia

Email: sry_rosita@unja.ac.id, simatupangsbr@yahoo.com, sylvia_unja@yahoo.com, ade_titinifita@yahoo.co.id

\begin{abstract}
ABSTRAK
Tujuan dari pengabdian kepada masyarakat tim fakultas ekonomi dan bisnis adalah untuk mencari keunikan desa mewujudkan desa wisata di Desa Jernih Jaya, untuk memiliki sejarah profil desa sehingga dapat dipromosikan dengan lebih baik. Metode yang digunakan adalah observasi lapangan dan wawancara kepada sesepuh atau tua tengganai Desa jernih Jaya. Hasil Pengabdian Kepada Masyarakat di Desa Jernih Jaya berupa profil sejarah yang mendukung terujudnya desa wisata, keunikan yang dimiliki Desa Jernih Jaya secara konkrit dapat terujudnya desa wisata, sarana promosi yang dimiliki Desa Jernih Jaya didalam mewujudkan Desa wisata.
\end{abstract}

Kata kunci: Desa Jernih Jaya, Desa Wisata, Keunikan Desa, Sejarah Desa.

\section{PENDAHULUAN}

Daya tarik sebuah desa, dimulai dari kehidupan penduduk desa yang unik yang tidak dapat ditemukan diperkotaan, suasana tradisional yang memiliki ciri dan nilai tertentu yang dapat menjadi daya tarik khusus bagi wisatawan untuk tinggal atau dekat dan belajar tentang kehidupan pedesaan merupakan gambaran dari sebuah desa wisata. Daya tarik wisata di suatu desa dapat meliputi keseluruhan kehidupan penduduk desa beserta kondisi fisik lokasi desa yang memungkinkan para wisatawan dapat berpartisipasi aktif didalam menjalankan aktivitas aktivitas seperti penduduk desa. Hampir seluruh desa di Kabupaten Kerinci memiliki sumber daya yang potensial untuk dikembangkan sebagai desa wisata karena memiliki pesona alam yang indah dan adat istiadat yang kental sehingga memiliki keunikan sebagai desa wisata.Salah satu desa yang memiliki keunikkan sebagai desa wisata adalah desa Jernih Jaya yang berada dikabupaten Gunung Tujuh.

Arida, Wiguna, Narka, \& Febrianti (2017) Desa wisata merupakan kawasan pedesaan yang memiliki beberapa ciri khas untuk dijadikan daerah tujuan wisata. Desa wisata disamping kekayaan alam memiliki penduduk yang masih memiliki tradisi dan budaya yang masih asli, dengan makanan yang khas, system dan hasil pertanian dan lingkungan sosial juga menjadi potensi kawasan desa wisata. Isnaini \& Muktiali (2015) keberadaan desa wisata akan berpengaruh terhadap aspek fisik dan aspek non fisik desa. Hadiwijoyo (2012) desa wisata merupakan kawasan pedesaan dengan keaslian pedesaan yang tercermin dari kehidupan masyarakatnya. Artina, Dewi, \& Yulianti (2018) desa wisata merupakan bentuk integrasi antara atraksi, akomodasi dan fasilitas pendukung yang dihadirkan dalam suatu tatanan masyarakat yang dalam tata krama dan tradisi yang berlaku.

Menurut Peraturan Menteri Pariwisata Republik Indonesia Nomor 13 Tahun 2018 tentang rencana strategis kementrian pariwisata Tahun 2018 - 2019 yaitu pengembangan wisata berbasis pedesaan akan menggerakkan ativitas ekonomi pariwisata dipedesaan yang akan 
mencegah urbanisasi masyarakat desa ke kota. Pengembangan wisata pedesaan akan mendorong pelestarian alam dan berdampak pada mereduksi pemanasan global. Mahmoudi, Haghsetan, \& Maleki (2011) Pariwisata yang berbasis di pedesaan akan berperan serta dalam meningkatkan perekonomian serta meningkatkan kesejahteraan masyarakat yang ada di lokasi itu sendiri. Kesejahteraan masyarakat akan meningkat seiring dengan semakin majunya pariwisata yang ada karena pariwisata ini akan mendorong aspek sosial serta ekonomi untuk ikut berkembang.

Desa Jernih Jaya sebagai desa wisata memiliki keunikan yang beranekaragam baik dilihat dari kekayaan alam, budaya dan hasil produksi yang menjadi sasaran kunjungan para wisatawan, keunikkan desa secara konkrit dapat digunakan dalam mempromosikan desa menjadi desa wisata. Untuk menggali keunikan desa dapat dilihat dari sejarah yang mendukung berdirinya desa dengan nilai nilai adat serta budaya yang ada didesa Jernih Jaya. Desa Jernih Jaya masih dalam tahap awal proses terujudnya desa wisata sehingga sejarah desa yang seharusnya dapat di jadikan sumber menggali keunikkan desa belum pernah dideskripsikan secara konkrit, sehingga sarana promosi desa Jernih jaya sebagai desa wisata juga masih sangat terbatas.

Dari analisis situasi diatas maka sangat penting menggali sejarah Desa Jernih Jaya dengan segala keunikan desa sehingga desa jernih jaya dapat memiliki sarana promosi untuk terujudnya desa wisata.

Desa Jernih Jaya merupakan salah satu desa yang berada di Kecamatan Gunung Tujuh, keunikan Desa Jernih Jaya masih sangat minim untuk di ketahui oleh masyarakat luas padahal Desa Jernih Jaya cukup potensial untuk dijadikan desa wisata, maka permasalahan yang terdapat di Desa Jernih Jaya dirumuskan bahwa Desa Jernih Jaya belum memiliki profil sejarah yang mendukung terujudnya desa wisata, belum tampak keunikan secara konkrit untuk terujudnya sebagai desa wisata dan belum memiliki sarana promosi untuk terujudnya Desa wisata.

Tujuan pendampingan yaitu membantu Desa Jernih Jaya untuk memiliki profil sejarah yang mendukung terujudnya desa wisata, menggali keunikan yang ada sehingga dapat dijadikan desa wisata dan membantu Desa Jernih Jaya memiliki sarana promosi untuk terujudnya Desa wisata. Urgensi kegiatan PPM FEB UNIVERSITAS JAMBI diharapkan dapat menjadi pendamping bagi Desa Jernih Jaya untuk membantu Desa Jernih Jaya memiliki profil sejarah yang mendukung terujudnya desa wisata, membantu Desa Jernih Jaya menggali keunikan yang ada sehingga dapat dijadikan desa wisata, membantu Desa Jernih Jaya memiliki sarana promosi untuk terujudnya desa wisata sehingga dapat dirasakan untuk khalayak luas seperti masyarakat Desa Jernih Jaya, masyarakat yang membutuhkan objek wisata di pedesaan, para aparat pedesaan dan khalayak lainnya.

\section{METODE}

Lokasi Pengabdian Kepada Masyarakat Fakultas Ekonomi dan Bisnis berada di Desa Jernih Jaya Kecamatan Gunung Tujuh Kabupaten Kerinci, alasan pemilihan lokasi adalah Desa Jernih Jaya sebagai desa wisata memiliki keunikan yang beranekaragam baik dilihat dari kekayaan alam, budaya dan hasil produksi yang menjadi sasaran kunjungan para wisatawan, keunikkan desa secara konkrit dapat digunakan dalam mempromosikan desa menjadi desa wisata. Waktu pelaksanaan yaitu selama 6 bulan, dengan tahapan tahapan yang dilakukan dalam pross PPM FEB UNJA yaitu persiapan, pelaksanaan serta tindak lanjut.

Metode yang digunakan untuk mendampingi Desa Jernih Jaya adalah dengan metode; Observasi Lapangan dan wawancara. Tim Pelaksana PPM FEB UNJA adalah dosen dosen di 
Jurusan Manajemen FEB UNJA yang memiliki kompetensi yang tidak diragukan lagi dalam mendampingi masyarakat pedesaan untuk dapat lebih maju. Target peserta PPM FEB UNJA adalah para sesepuh atau tua tengganai dan para pengelola BUMDES di Desa Jernih Jaya.

\section{HASIL DAN PEMBAHASAN}

\section{Wisata Alam Dan Keunikan Budaya Di Desa Jernih Jaya}

Panorama yang dimiliki Desa Jernih Jaya masih sangat alami, dengan keindahan alam yang sangat indah, udara yang masih diselimuti embun disaat pagi hari, rawa yang dialiri air yang sangat jernih, dengan pepohonan pepohonan yang rindang dan hewan hewan liar yang berkeliaran di sepanjang rawa. Pemandangan khas area rawa yang ditutupi rumput Leersia hexandra dan Eugenia spicate dan sebagai maskot rawa bento yang juga dinikmati saat perjalanan menggunakan perahu bermotor (perahu ketek) yang disediakan oleh pengelola. Keunikan wisata alam yang dimiliki Desa Jernih Jaya dilihat dari pemandangan desa Jenih Jaya yang terlihat sangat indah dilengkapi dengan Gunung Kerinci yang tampak dengan sangat jelas dari pemukiman penduduk seolah-olah mengikuti setiap langkah orang yang berada disekitar desa Jernih Jaya. Rawa Bento dikembangkan oleh masyarakat melalui Bumdes dengan pendanaan yang berasal dari dana desa. Rawa ini merupakan lahan basah pada ketinggian 1.333 mdpl, dengan luas sekitar 1.000 ha. Rawa Bento menampung aliran sungai yang berasal dari gugusan Pesona Wisata Jambi Gunung Kerinci, Gunung Tujuh, Gunung Sangkar dan sekitarnya. Karena pendangkalan, danau lama-lama menjadi rawa. Rawa ini tertutup oleh rumput bento dan menjadi hutan rawa, sehingga dikenal dengan nama Rawa Bento.

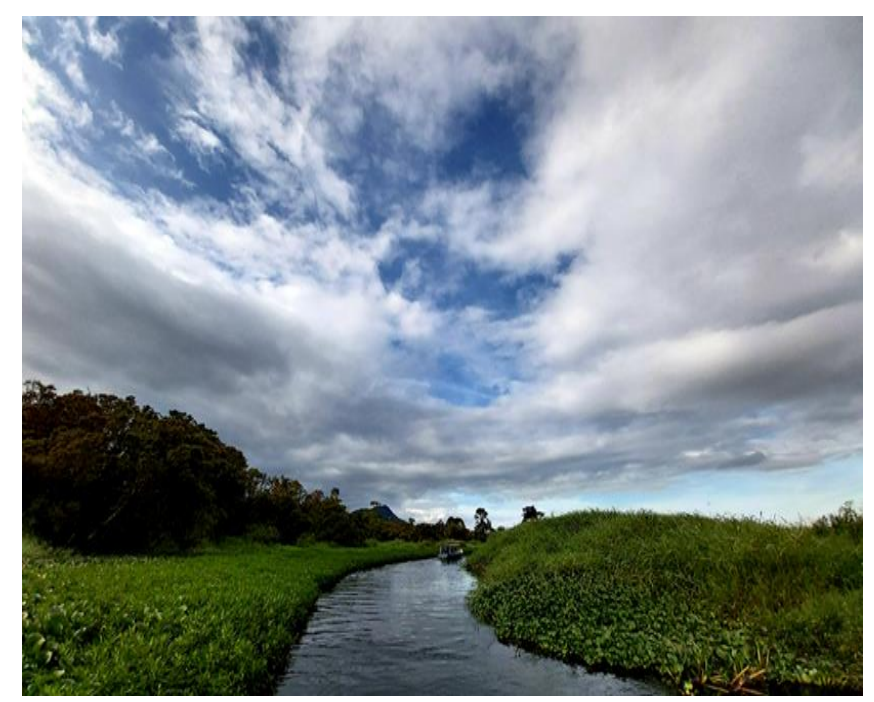




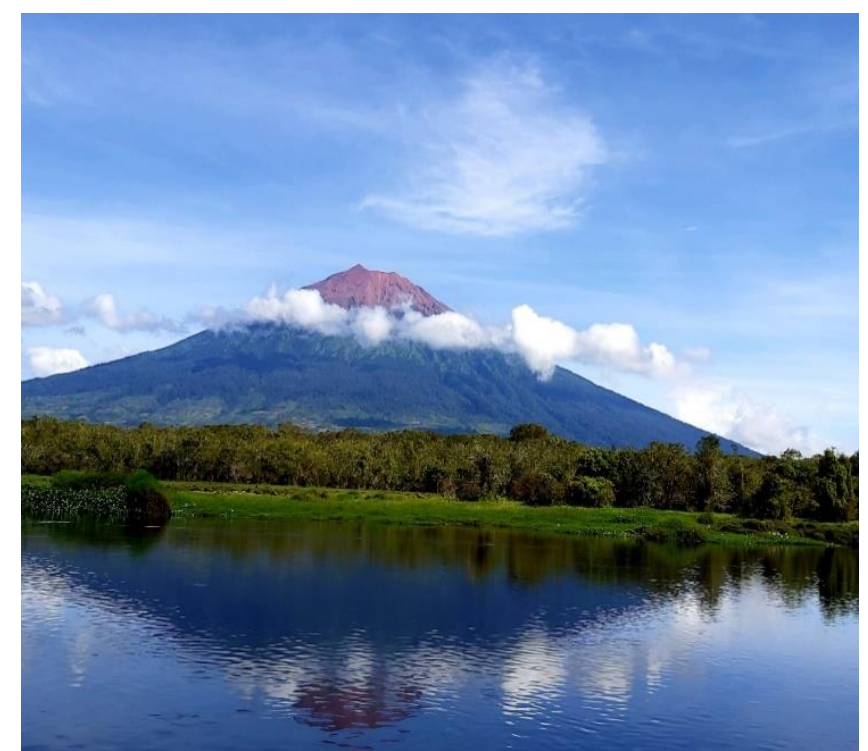

Sumber : Dokumentasi Tim Pengabdian Pada Masyarakat (2020)

Ekosistem Rawa Bento terdiri dari rumput rawa gambut yang didominasi oleh rumput bento dan beberapa jenis rumput dengan batang bersegi (famili: Cyperaceae); hutan rawa kerdilnya terdiri atas pohon-pohon Eugenia spicata, Palaquium sp.,Syzygium sp., Elaeocarpus sp., Ficus spp dan lainnya. Tak hanya keunikan rawanya yang ditumbuhi vegetasi menjadi pemandangan yang indah, tetapi juga beberapa jenis burung yang hidup di daerah ini. Antara lain burung jernih, burung layang-layang dan putih, bebek liar dan kerbau liar, serta masih banyak lagi hewan hewan liar yang terdapat di Rawa Bento. Sungai dan danau Bento menjadi ekosistem ikan seperti ikan semah (Tor sp.), ikan pareh (Tor tambroides), ikan saluang (Rasbora lateristriata) dan belut (Monopterus albus). Di sepanjang tepi sungai dan danaunya banyak tanaman enceng gondok (Eichornia crasipes) dan kayu apu (Pistia stratiotes)..

Keanekaragaman burung yang hidup di wilayah rawa Bento ini menjadi daya tarik tersendiri. Bagi pengunjung yang hobi melakukan pengamatan burung, di tempat ini dimanjakan oleh berbagai jenis burung unik. Antara lain, kuntul kerbau, kuntul kecil, bebrapa jenis raja udang, beberapa jenis raptor, itik gunung, berkik, mandar padi sintar, trinil semak, trinil pantai, dsb. Bagi penggemar birdwatching, lokasi ini menjadi surganya pengamat burung. Lima diantara 13 jenis burung air adalah burung air migran yang hanya dapat ditemukan di waktu-waktu tertentu. Burung-burung ini tersebar di empat tipe lahan basah, yaitu di rawa danau 7 jenis, di rawa rumput 8 jenis, di sungai 8 jenis dan di sawah 6 jenis. Selain Burung, kita dapat melihat simpai (Presbytis melalophos) yang bergantungan di atas pohon.

Para wisatawan baik wisatawan asing maupun wisatawan lokal akan disuguhi budaya yang masih sangat kental berupa adat istiadat masyarakat Desa Jernih Jaya. Sebagai desa wisata desa Jernih Jaya memiliki tujuan pariwisata dengan mengintegrasikan panorama alam, fasilitas umum, fasilitas pariwisata, aksesibilitas, yang disajikan dalam kehidupan masyarakat yang menyatu dengan tata cara dan tradisi yang sesuai dengan adat istiadat dan norma norma yang berlaku di Desa Jernih Jaya. Aliran sungai Rawa Bento yang sangat tenang membuat wisatawan merasa nyaman, tidak hanya itu, pemandangan disekeliling Rawa sangat indah, sehingga banyak kegiatan yang ditawarkan di sana. Kegiatan yang ditawarkan di Rawa Bento yaitu Berkemah, memancing, hunting photo, pengamatan burung, piknik, flora dan fauna. Para wisatawan yang ingin berkemah menikmati suasana malam di Rawa Bento disiapkan peralatan berkemah dengan cara menyewa. 


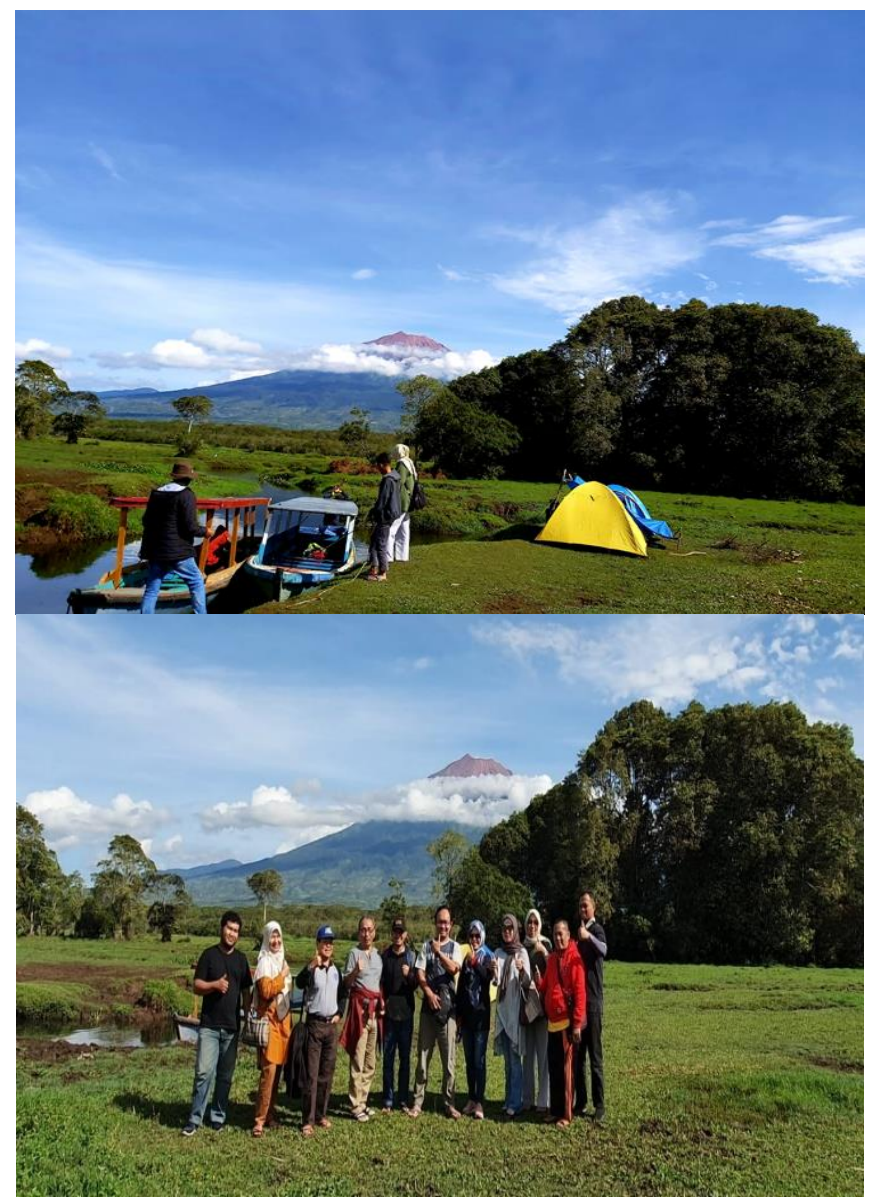

Sumber : Dokumen Tim Pengabdian Pada Masyarakat (2020)

Bagi wisatawan yang ingin menuju dataran Rawa Bento pengelola BUMDes akan menyiapkan fasilitas transportasi perahu ketek yang merupakan satu satunya alat transfortasi untuk menuju dataran Rawa Bento. Jenis fauna yang terlihat di sepanjang jalur yaitu seperti kupu-kupu (Delias fruhstorferi), capung (Aesha sp), dan monyet ekor panjang (Macaca Fascicularis). Beberapa jenis burung air migran seperti trinil semak ( Tringa glareola), trinil pantai (Tringa hypoleucos), dan berkik rawa (Gallinago megala). Selain burung-burung migran sedikitnya terdapat 10 jenis burung air lain yang merupakan penghuni tetap dari Rawa Bento. Selain burung air terdapat 38 jenis burung lain yang juga menghuni hutan rawanya. Menurut masyarakat sekitar terdapat burung belilis kembang (Dendrocygna arcuata) yang endemik di kawasan Rawa Bento.

Ada juga kerbau milik masyarakat yang dibiarkan hidup liar di Rawa Bento. Kerbau dibiarkan hidup liar untuk menambah kesan alami Rawa Bento. Panorama alam yang dapat dinikmati pengunjung pada jalur yang tersedia sebagai target kunjungan wisatawan di Rawa Bento merupakan daya tarik yang tidak dapat di temui di tempat lain, sehingga keunikkan Rawa Bento dapat dijadikan Desa Jernih Jaya sebagai desa wisata.

\section{Wisata Agro Kopi}

Perkebunan kopi di Desa Jernih Jaya dikelola dengan sangat baik, sehingga menghasilkan kopi berkualitas ekspor yang mempunyai nilai tinggi. Jenis kopi desa Jernih Jaya adalah kopi Arabika. 


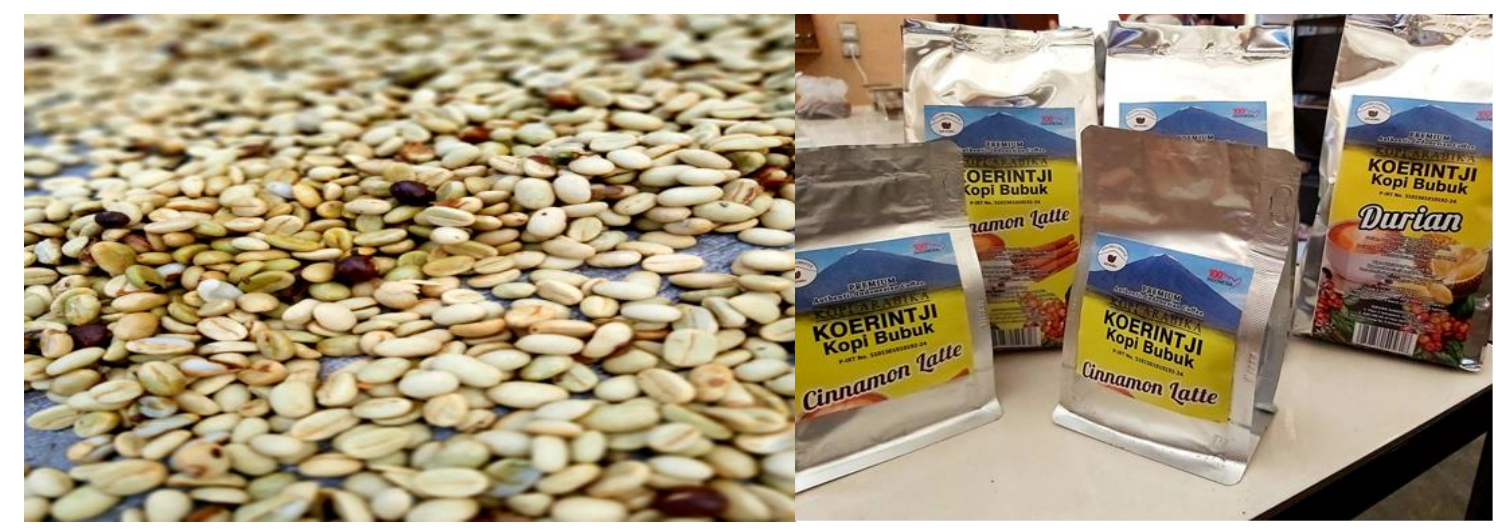

Sumber: Dokumen Tim Pengabdian Pada Masyarakat (2020).

Kopi Arabika Kerinci dibina melalui Koperasi Koerintji Barokah yang didirikan tahun 2017. Koperasi Koerintji Barokah beranggotakan 320 petani yang tersebar di Kecamatan Gunung Tujuh, Kayu Aro, dan Kayu Aro Barat dengan luas lahan sekitar 140 hektar. Berdasarkan hasil wawancara dengan Bapak Triyono sebagai manajer Kopi Korintji Barokah menyebutkan agar Kopi Korintji menjadi kopi kualitas ekspor, maka kualitas kopi harus selalu dijaga. Biji Kopi Korintji adalah Green Bean yang melalui proses panjang yang berkualitas. Kopi Korintji Barokah yang diekspor keluar negeri masuk kategori Specialty, menurut Specialty Coffee Association of America (SCAA) nilainya diatas 80. Adapun skor nilai menurut SCAA sebagai berikut; skor 90 - 100 kopi specialty kualitas Outstanding, skor 85- 89.99 kopi specialty kualitas Excellent, skor 80-84.99 kopi specialty kualitas Very Good, skor di bawah 80 bukan kopi specialty. Kategori specialty dan premium kelasnya beda, pasarnya beda dan harganya juga beda. Kopi kategori specialty diekspor ke luar negeri dan kopi kategori premium dijual di dalam negeri, tapi ada juga Kopi kategori specialty dijual di pasar lokal.

\section{Wisata Kebun Kentang dan Bawang Merah}

Hasil perkebunan yang menjadi daya tarik desa Jernih Jaya selain hasil perkebunan Kopi yaitu hasil perkebunan kentang dan bawang merah yang di jual ke Kota Jambi dan ke Provinsi Sumatera Barat. Panorama yang Indah dan sangat alami menjadikan perkebunan kentang dan bawang merah dapat menjadi keunikan desa dan menjadikannya desa wisata. Sambil berwisata dan mengabadikannya dengan berfoto, para wisatawan juga dapat membeli hasil perkebunan kentang dan bawang merah langsung dari petani. 


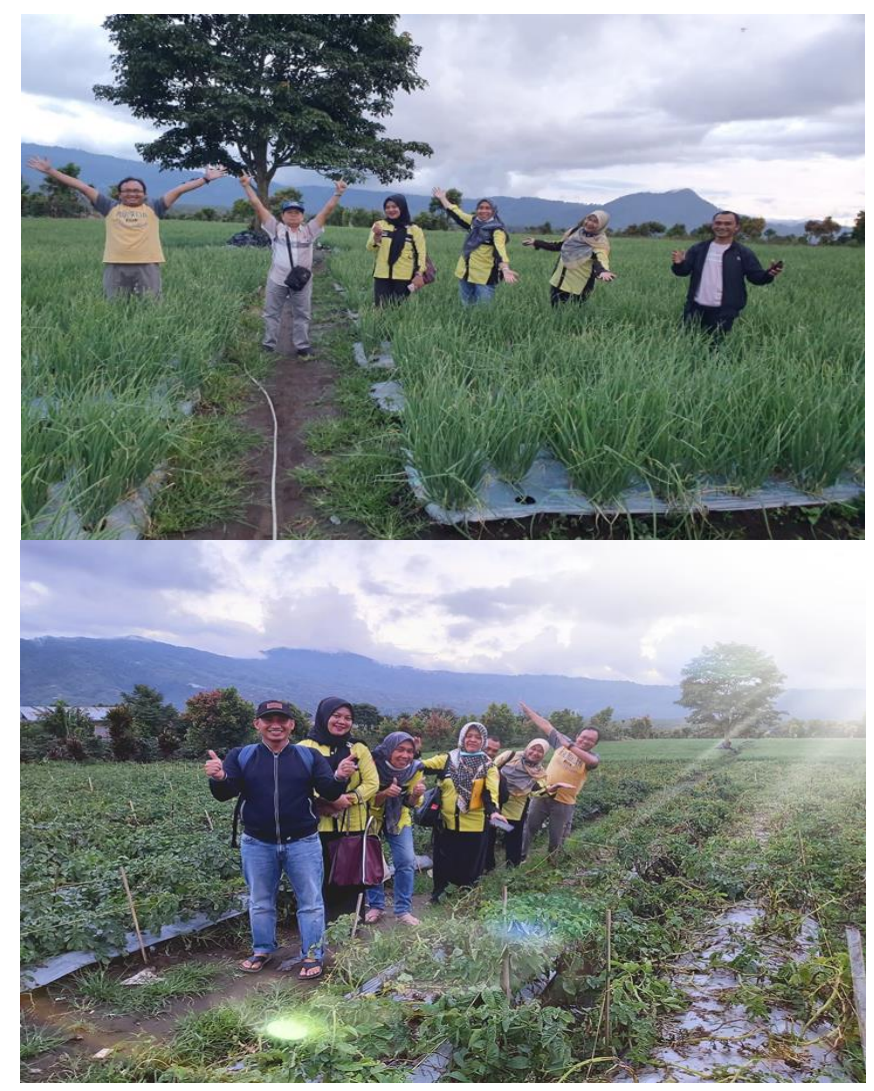

Sumber: Dokumen Tim Pengabdian Pada Masyarakat (2020).

\section{Home Stay Desa Jernih Jaya}

Panorama alam yang indah, budaya yang masih sangat kental hasil perkebunan dengan kualitas terbaik sangat menunjang Desa Jernih Jaya menjadi Desa Wisata. Kenyamanan para wisatawan yang berkunjung ke desa Jernih Jaya didukung akomodasi seperti home stay yang di kelola para warga Desa Jernih Jaya. Warga desa Jernih jaya sudah menyiapkan rumahnya untuk disewakan kepada para wisatawan dengan harga terjangkau dan dilengkapi dengan fasilitas fasilitas pendukung sehingga para wisatawan merasa seperti tinggal dirumah sendiri. Para pemilik homestay akan memberikan informasi yang dibutuhkan mengenai tempat wisata maupun informasi lainnya yang dibutuhan wisatawan.

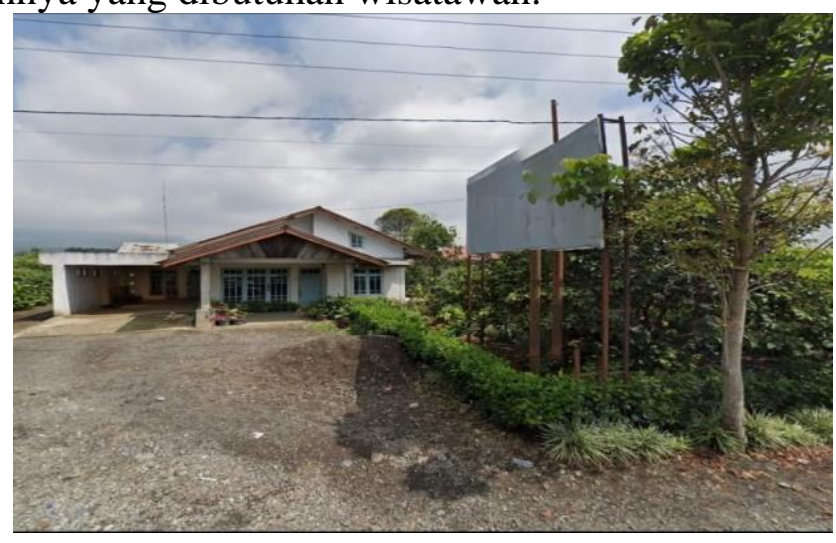




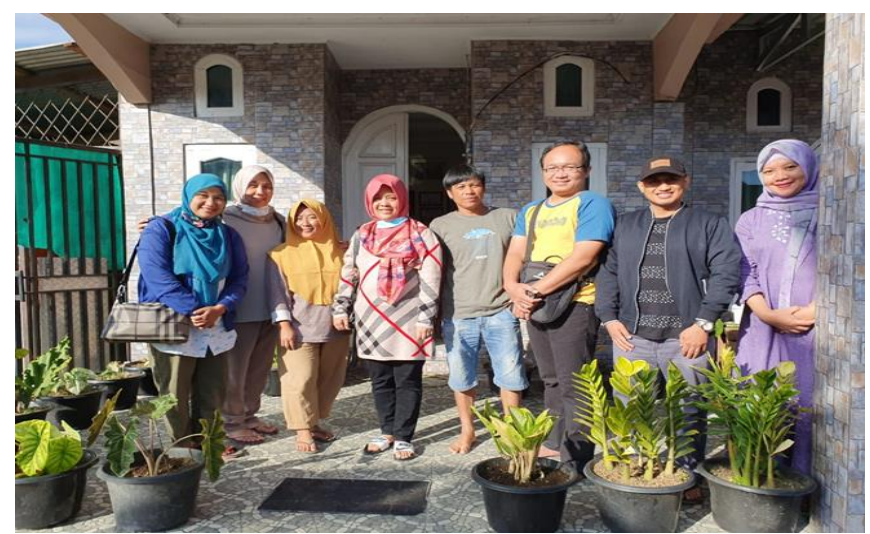

Sumber: Dokumen Tim Pengabdian Pada Masyarakat (2020).

\section{Sarana promosi untuk terujudnya Desa wisata di Desa Jernih Jaya Kecamatan Gunung Tujuh Kabupaten Kerinci}

Konsep pemasaran berorientasi konsumen, dimana pemasaran harus dirancang berdasarkan kebutuhan dan keinginan konsumen. Pemasaran berbasis ICT merupakan kebutuhan konsumen dewasa ini dan alternatif terbaik yang bisa dipilih melalui media promosi. Secara khusus, adopsi tekhnologi informasi khuisusnya media sosial dapat digunakan untuk berbagai tujuan antara lain pemangku kepentingann, serta promosi desa wisata secara intensif kepada wisatawan. We Are Social, sebuah agensi marketing sosial melaporkan bahwa pengguna aktif internet di Indonesia sebanyak 72,7 juta pengguna. Sedangkan pengguna media sosial sebanyak 72 juta pengguna, dimana 62 penggunanya mengakses media sosial menggunakan perangkat telepon pintar atau lebih sering dikenal dengan Smart Phone. (sumber: https://id.techinasia.com/laporan-pengguna-website-mobile-media-sosial-indonesia). Oleh sebab itu, media sosial dianggap media yang paling efektif dalam melakukan promosi baik itu barang ataupun jasa. Dengan adanya media sosial dapat mengirimkan pesan berantai yang akan disebarkan oleh orang lain secara terus menerus. Pesan berantai itulah yang dimanfaatkan sebagai media promosi.

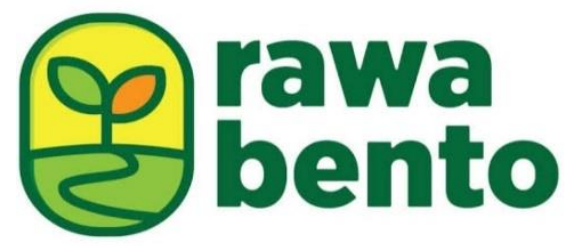

Sumber: Bumdes Desa Jernih Jaya (2020)

BUMDES Desa Jernih Jaya yang juga sebagai pengelola Rawa Bento memanfaatkan media sosial sebagai media promosi Wisata Alam Rawa Bento dan Potensi Pariwisata, berupa; Instagram disebut juga dengan IG atau Insta, merupakan aplikasi berbagi foto dan ideo yang memungkinkan pengguna mengambil foto, mengambil ideo, menerpkan filtetr digital, dan membagikannya ke berbagai layanan jejaring sosial, termasuk milik instagram sendiri. Instagram bisa dijadikan sebagai media promosi karena menyediakaninformasi yang menarik melalui foto-foto dan ideo yang menarik. Akun resmi IG Rrawa Bento @rawabento dikelola langsung oleh Bumdes Desa Jernih Jaya. Berbagai foto dan informasi tentang tentang Rawa Bento tersaji dalam akun IG tersebut, akun ini diikuti oleh 2.688 pengikut dan bisa dilihat oleh wisatawan. Facebook selain Instagram, Facebook juga digunakan oleh BUMDES Desa Jernih 
Jaya untuk mempromosikan Rawa Bento. Dengan Facebook, pengelola akun bisa berkomunikasi dengan wisatawan, dan bisa saling berbagi testimony, Website merupakan situs internet World Wide Web atau Waring Wera Wanua biasa disingkat dengan WWW adalah suatu ruang informasi yang berisi halaman web, file, gambar, video, dan konten online lainnya yang dapat diakses dan dicari melalui browser web, dengan adanya web memudahkan orang untuk terhubung dengan hampir semua tempat di dunia. Website tentang Rawa Bento dan Potensi Wisata Desa Jernih Jaya dibuat oleh agen perjalanan yang berada di Provinsi maupun Kota sungai penuh untuk mempromosikan objek wisata di kabupaten kerinci, termasuk rawa bento dan menawarkannya dalam bentuk paket wisata. Agen Perjalanan wisata menawarkan paket-paket perjalanan kepada wisatawan, dan ketika ada wisatawan yang ingin mengunjungi Rawa Bento dan desa jernih Jaya, biasanya mereka berkoordinasi dengan BUMDES Desa Jernih Jaya, dan Brosur merupakan salah satu alat promosi yang digunakan Bumdes Jernih Jaya untuk mempromosikan desa wisata di Jernih Jaya dengan sejumlah informasi yang ditawarkan kepada para wisatawan tentang keunikkan desa Jernih Jaya. Berikut ini adalah beberapa brosur yang dicetak Desa Jernih Jaya untuk mempromosikan desa wisata di Desa Jernih Jaya.

Tim pengabdian FEB UNJA tahun 2020 telah membuat Website dan Link promosi wisata Desa Jernih Jaya yaitu Wisata.unja.ac.id berisi tentang objek wisata yang terdapat di Desa Jernih Jaya, Fasilitas akomodasi yang tersedia termasuk link untuk booking. Tujuannya adalah untuk mempermudah wisatawan mengenal objek-objek wisata yang tersedia, fasilitas akomodasi yang disediakan dan link untuk booking bila diperlukan.

\section{KESIMPULAN}

Sampai sejauh ini Dukungan Promosi yang dilakukan untuk mewujudkan Desa Jernih Jaya sebagai desa wisata dinilai masih belum memadai. Media Sosial yang digunakan BUMDES Desa Jernih Jaya belum cukup. Perlu didukung kemampuan atau kapasitas kelembagaan dalam mengelola potensi-potensi pariwisata Di Desa Jernih Jaya meliputi kapasitas organisasi yang mendukung Pariwisata dan kapasitas individu yaitu masyarakat desa sendiri yang menyokong secara langsung pengembangan desa wisata. Perlu juga dirintis kemitraan dengan pihak eksternal seperti investor, agen perjalanan wisata, agen promosi dalam pengembangan potensi wisata, pengelolaan atraksi wisata, penyediaan cindramata serta pelayanan kepada wisatawan. Masyarakat desa Jernih Jaya perlu mendapatkan peningkatan kapasitas sebagai individu melalui pelatihan dan program peningkatan kapasitas masyarakat yang diadakan dinas pariwisata dan organisasi lainnya untuk menambah menambah wawasan, pemahaman dan pengaplikasian konsep desa wisata sehengga mereka siap menerima wisatawan. Fasilitas Pelayanan Wisatawan disekitar Rawa Bento dan Desa Jernih Jaya juga masih minim. Belum tersedia papan nama atau baliho, juga papan penunjuk arah lokasi wisata Rawa Bento maupun fasilitas umum lainya. Pada Dermaga Rawa Bento belum tersedia tempat parkir, mushola dan toilet dan kantin, dan penjualan souvenir atau cindramata.

\section{REFERENSI}

Arida, I. N. S., Wiguna, P. P. K., Narka, I. W., \& Febrianti, N. K. O. (2017). Development Planning of Tourist Village Using Participatory Mapping (Case study: Mambal Village, Badung Regency, Indonesia). IOP Conference Series: Earth and Environmental Science, 98(1). https://doi.org/10.1088/1755-1315/98/1/012044

Artina, S. V., Dewi, P. W., \& Yulianti, T. R. (2018). SWOT Analysis of the Development of the Tourist Cibuntu Village, Cibuntu Regency, West Java. IOP Conference Series: Earth 
and Environmental Science, 145(1). https://doi.org/10.1088/1755-1315/145/1/012074

Hadiwijoyo, S. S. (2012). PERENCANAAN PARIWISATA PERDESAAN BERBASIS MASYARAKAT Sebuah Pendekatan Konsep. In Graha Ilmu (Pertama). Yogyakarta.

Isnaini, N. W., \& Muktiali, M. (2015). Pengaruh Keberadaan Desa Wisata Samiran Terhadap Perubahan Lahan, Ekonomi, Sosial dan Lingkungan. Jurnal Teknik PWK UNDIP, 4(3), 389-404.

Mahmoudi, B., Haghsetan, A., \& Maleki, R. (2011). Investigation of Obstacles and Strategies of Rural Tourism Development Using SWOT Matrix. Journal of Sustainable Development, 4(2), 136-141. https://doi.org/10.5539/jsd.v4n2p136 